of observations for the purpose of analysis and evaluation of the quality of NSA, their effectiveness. The implementation of this function is ensured by the activities of state bodies, which involves the systematic generalization and systematization of legal information; the algorithm of action for determining priorities, planning, methods of information gathering, crosschecking information, reporting, information analysis.

Key words: legal monitoring, information function, efficiency of legislation, normative legal acts, information society.

DOI: 10.33.66.3/2524-017X-2019-10-176-180

УДК 340

\author{
Михайло Андрійович Марченко, \\ аспірант відділу теорії держави і права \\ Інституту держави і права \\ ім. В.М. Корецьккого НАН Украӥни
}

\title{
НОРМАТИВНО-ПРАВОВЕ ЗАКРІПЛЕННЯ \\ ПРАВА НА ПОВАГУ ДО ЛЮДСЬКОЇ ГІДНОСТІ \\ В УКРАЇНСЬКІЙ ТА ЄВРОПЕЙСЬКІЙ ПРАВОВИХ СИСТЕМАХ (ПОРІВНЯЛЬНО-ПРАВОВИЙ АСПЕКТ)
}

Постановка проблеми. Демократична та правова держава відповідає перед громадянами за свою діяльність. Саме тому питання верховенства права, захисту та поваги до основоположних прав і свобод людини, зокрема їі честі та гідності є одним із найголовніших питань, як внутрішньої, так і зовнішньої політики будь-якої розвиненої країни.

Як зазначає Н. Оніщенко, демократична державна влада - це постійний партнер особи, що самовдосконалюється. Вона дієвий і активний прибічник свободи, фізичного і культурного розвитку людини. Ось чому, розглядаючи взаємозв'язок держави, права і свободи особи, необхідно зазначити, що існують права і свободи, які в жодному разі не можуть обмежуватися - це природні права і свободи людини [1, с.72]. Основний зміст багатьох юридичних гарантій свободи полягає в забезпеченні необхідних умов для нормального життя та активної діяльності громадян у суспільстві, у зв'язку із чим непересічного значення набуває нормативно-правове закріплення права на повагу до людської честі та гідності, а також налагодження дієвих механізмів правового реагування на порушення змісту та суті зазначеного права.

Аналіз останніх досліджень та публікацій. В українській правовій думці проблематиці розвитку та становлення, захисту та нормативно-правового закріплення прав і свобод людини, а також честі та гідності особи присвячено низку наукових праць. Проте стан дослідження вказаної проблематики, на жаль, є значною мірою віддзеркаленням реальної картини із практичної реалізації вказаного права, тому актуальність досліджень у цій сфері залишається поза сумнівом, через що потребує додаткового розгляду та деталізації. Втім, необхідно віддати належне попереднім напрацюванням, хочемо зазначити, що цією проблематикою в різні часи займалися: Н. Кузнецова, Н. Оніщенко, О. Петришин, О. Скрипнюк, С. Стеценко, С. Шевчук, Ю. Шемшученко, О. Ющик тощо.

Мета статті полягає у порівняльно-правовому аналізі нормативно-правового закріплення, одного із основоположних компонентів комплексу прав і свобод людини - права на повагу до людської гідності, як у європейському правовому просторі, так і вітчизняному, зокрема, надання пропозицій щодо вдосконалення механізму захисту вищезазначеного природного та невід’ємного права особи.

Нормативно-правове закріплення права на повагу до честі і гідності людини затверджено на рівні усіх основних міжнародних нормативно-правових актів. Зміст вказаного права полягає у встановленій забороні на вчинення будь-яких дій, пов'язаних із приниженням гідності, неправомірним поводженням чи неспівмірним покаранням.

Так, науковець В. Розвадовський стверджує, що недоторканність гідності та честі людини є особистим немайновим благом, яке є невіддільним від особистості і яким певний індивід наділений від народження [4, с. 80]. 
Марченко М. А. Нормативно-правове закріплення права на повагу до людської гідності...

Отже, відповідно до статті 1 Конвенції про права дитини від 1989 р. дитиною є кожна людська істота до досягнення нею 18 річного віку, згідно зі ст. 16 вказаного нормативно-правового акта, забороняється будь-яке незаконне посягання на їі гідність та честь [3].

Зокрема, відповідно до статті 5 Загальної декларації прав людини, ніхто не повинен піддаватися катуванню або жорстокому, нелюдському або такому, що принижує честь і гідність особи поводженню і покаранню [5]. Ідентичне формулювання щодо заборони поведінки, яка може призвести до приниження честі і гідності особи, закріплено в ст. 3 Конвенції про захист прав людини і основоположних свобод.

Згідно з Міжнародним актом про громадянські і політичні права, держави, які беруть участь у вказаному Пакті, визнають гідність, як ту категорію, яка властива всім членам людської сім'ї, зазначаючи, що всі права випливають із властивої людській особі гідності [6]. Враховуючи вищезазначене, українські вчені стверджують, що на міжнародному рівні людська гідність визнається джерелом прав людини.

Непересічного значення в цьому контексті набуває вивчення європейської практики реалізації прав та свобод і законних інтересів людини. Не можливо не зробити акцент на нормах європейської правової системи, які створили фундамент сучасних європейських цінностей та правових гарантій.

Так, відповідно до змісту окремих положень Договору про Європейський Союз (ст. 2), система правових орієнтирів, яка була закладена в його основу, включає в себе повагу до людської гідності, свободи, демократії, рівності, верховенства права та повагу до прав людини. Вищезазначені цінності є загальними для країн-членів Європейського Союзу, як тієї спільноти, для якої $є$ притаманним плюралізм, недискримінація, терпимість, справедливість, солідарність, а також рівність між чоловіком та жінкою [7].

Також питання поваги до людської гідності країнами-членами СС виносяться на перший план не лише у внутрішньополітичних аспектах діяльності, а також у питаннях зовнішньої політики.

Відповідно до статті 21 глави 1 Загальних положень щодо зовнішньополітичної діяльності Союзу, зазначається, що ЄС прагне просувати у всесвіті демократію, правову державу, загальність на неподільність прав людини і основоположних свобод, повагу до людської гідності, принципи рівності та солідарності.

Н. Оніщенко вважає, що говорячи про засади правового становища особи в $\mathrm{CC}$, необхідно усвідомлювати, що це питання складне, кроссекторальне і потребує системного викладення, а також дослідження певної системи прав, свобод і законних інтересів особи. Необхідно усвідомлювати, що принцип правового становища людини і громадянина являє собою основоположні начала та керівні засади права [8, с. 73].

Зокрема, посилаючись на Хартію основних прав Свропейського Союзу 2000 р. (далі - Хартія), особистісні права і свободи закріплені у таких главах, як «Гідність» (гл. 1) та «Свободи» (гл. 2).

У зв'язку із переважаючою думкою щодо гідності людини, як одного із «найболючіших» прав, вказана сфера потребує більш детального вивчення. Проте, безумовно, важливою гарантією цього права $€$ чітка заборона тортур, приниження людської гідності, нелюдських покарань.

Аналізуючи нормативно-правові документи країн $€ C$, було зроблено висновок про те, що у більшості нормативних установлень щодо членів $С С$ питання, пов'язані із правом людини на визнання іiї гідності, займають пріоритетні позиції.

Наприклад, відповідно до статті 1 Основного закону Федеративної Республіки Німеччини, гідність людини визнається недоторканою, а повага з боку державної влади є гарантованою [8].

Також, посилаючись на окремі положення Конституції Польщі, а саме - II розділ, який має назву «Свободи, права та обов'язки людини і громадянина», гідність людини закріплена як природна та невідчужувана і визнається у якості джерела свободи та прав людини і громадянина [9].

Конституція Грецької Республіки у ст. 2 проголошує повагу до гідності особи та встановлює необхідність захисту вказаного невідчужуваного від людини права, покладаючи одночасно на державу обв'язок щодо відповідного та належного захисту [10].

Важко переоцінити сьогодні значення в європейському просторі права на повагу до гідності особи, яке покликане забезпечувати однакові умови для реалізації прав і свобод всіма рівними суб'єктами правовідносин, усвідомлюючи кожним учасником правовідносин свого значення та унікальності. На думку видатного українського вченого А. Селіванова, «людська гідність» для суспільства і держави характеризує стандарт демократії, що має підтверджуватися своїм визначальним соціально-політичним значенням для всіх правовідносин, які становлять права людини». 
В Україні питання, пов'язані із конституційною гарантією захисту честі та гідності людини, вперше були зафіксовано в 1992 р. в офіційному проекті Конституції України, підготовленою робочою групою відповідної Конституційної комісії, яку очолив видатний професор Л. Юзьков. Як зазначають провідні українські дослідники, саме в цьому фрагменті історії України, було закладено подальший вектор розвитку української правової системи на шляху до розбудови демократичної країни, беручи за основу перевірені часом європейські стандарти та правові критерії.

Законодавець у ст. 28 Основного Закону України закріплює право особи на людську гідність, проте у більшості випадків поза увагою науковців та практиків залишається те, що право на людську гідність також закріплюється ст. ст. 3 і 21 Конституції України; це право входить до складу прав i свобод, однак «стоїть начебто перед ними»[11, с. 8].

На думку С. Вдовіченко, ст. 3 Основного Закону України містить приписи, які дають підстави вважати людську гідність, поряд із життям і здоров'ям та іншим, елементом провідного права людини - можливістю вільно, на власний розсуд формувати розвиток своєї особистості. Так само i ст. 21 Конституції України гарантує свободу і рівність людей у гідності та правах. Тобто з моменту народження гідність кожного $є$ однаковою, «рівною» з іншими. Усвідомлення цього сприяє формуванню у кожної особи почуття власної гідності, очікування поваги до неї з боку інших людей, установку на відстоювання своїх прав, а також визнання нею рівних прав інших людей [2, с. 62].

Таким чином, як зазначають лідери української юридичної думки, право на людську гідність фактично існує в українській правовій системі у двох вимірах: беручи до уваги ст. ст. 3 та 21 Конституції України - як елемент провідного права особи, сутність природних прав та аналізуючи ст. 28 Основного Закону - конкретно визначене позитивне право.

Окрім цього, необхідно зазначити про цивільно-правовий захист честі і гідності особи в українському законодавстві.

Так, наведена категорії прав особи, згідно зі ст. 201 Цивільного кодексу України (далі - ЦК України) відноситься до особистих немайнових благ, разом із життям здоров'ям, репутацією, а також іншими благами.

Зокрема, оскільки згідно зі ст. 275 ЦК України особисті немайнові права можуть бути предметом цивільно-правового захисту у разі їх порушення, то неможливо не акцентувати увагу на тому, що законодавець недарма у ст. 297 ЦК України закріплює нормативний припис про те, що кожен має право на повагу його гідності та честі, чітко зазначаючи, що гідність та честь фізичної особи є недоторканними.

Соціальна обумовленість досліджуваної категорії прав є беззаперечною, проте, на жаль, кримінальна-правова відповідальність, за посягання на міжнародно-визнане право особи на повагу до їі честі та гідності, прямо не передбачена.

Разом $з$ тим Кримінальний кодекс України в Особливій частині має третій розділ під назвою «Злочини проти волі, честі та гідності особи», відповідно до норм якого встановлюється кримінальна відповідальність за незаконне позбавлення волі або викрадення людини (ст. 146), захоплення заручників (ст. 147), підміну дитини (ст. 148), торгівлю людьми або іншу незаконну угоду щодо людини (ст.149), експлуатацію дітей (ст. 150), використання малолітньої дитини для заняття жебрацтвом (ст. 150-1) та незаконне поміщення в психіатричний заклад (ст. 151).

Висновки. Враховуючи вищевикладене, необхідно зазначити про те, що гідність людини, право, яке вона має від народження, $є$ однією із найвищих соціальних цінностей, яке стоїть поряд із життям і здоров'ям, недоторканністю та безпекою індивіда. Завдяки категорії гідність, людина має можливість усвідомлювати свою значущість у суспільстві, шляхом реалізації іiі духовних, фізичних та моральних якостей та, незалежно від ії відношення до певної спільноти, як частини людства.

Проте, на превеликий жаль, сьогодні в українській правовій системі право на непорушність гідності людини $є$ недооціненим, а його нормативно-правове закріплення має суто формальний характер.

Українські дослідники вважають, що проблематика забезпечення права на людську гідність, криється не стільки у законодавчій площині, скільки у правозастосовній практиці, у зв'язку із відсутністю концепції визначення меж цього права, оскільки, по факту, порушення майже будь-якого права людини так чи інакше може принизити ії гідність. Наприклад, вищезазначене цілком співвідноситься із завданням моральної шкоди, що все більше знаходить своє відображення у суспільно-політичних реаліях сьогодення, проте у зв'язку із відсутністю належних механізмів правового регулювання, отримати компенсацію моральної шкоди майже неможливо. 
Таким чином, спираючись на результати аналізу, міжнародних нормативно-правових актів, основних законів країн-членів $Є С$, Конституції України та норм вітчизняного законодавства, а також юридичної літератури разом із дослідженнями провідних науковців у сфері забезпечення прав і свобод людини, можна сформулювати шляхи вирішення проблеми захисту права особи на повагу до ії гідності:

- дослідити категорію «гідність людини» у порівняльно-правовому аспекті, з метою розроблення критеріїв та визначення меж вказаної категорії $з$ числа основоположних прав людини;

- підготувати пропозицій щодо вдосконалення українського законодавства у сфері охорони прав та свобод людини і громадянина, зокрема в контексті забезпечення та реалізації права на повагу до гідності особи;

- закріплення терміна «гідність» на законодавчому рівні, а також встановлення прямої кримінально-правової відповідальності за посягання на гідність людини як найвищу соціальну цінність;

- розробити науково-практичні рекомендації для студентів юридичного профілю щодо механізмів захисту гідності людини та порядку звернення до судових установ, у разі порушення такого права з боку державних органів чи органів місцевого самоврядування, організацій будь-якої форми власності, а також третіх осіб.

\section{Список використаних джерел}

1. Оніщенко Н. Свобода гідність та рівність людини крізь європейський фокус / Н. Оніщенко // Матеріали міжнародного науково-практичного семінару, присвяченого пам’яті Л. Юзькова. - 2018. - С. 72-74.

2. Вдовіченко C. Право на людську гідність: українська теорія і практика у контексті європейського досвіду / С. Вдовіченко, В. Кампо // Вісник Конституційного Суду України . - 2012. - №4. - С. 56-68.

3. [Електронний ресурс]. - Режим доступу : http://www.irf.ua/knowledgebase/publications/npm_2013/6

4. Розвадовський В. Проблеми правового захисту й охорони честі та гідності людини в Україні / В. Розвадовський // Матеріали міжнародного науково-практичного семінару, присвяченого пам'яті Л. Юзькова. - 2018. - С. 79-85.

5. [Електронний ресурс]. - Режим доступу : https://zakon.rada.gov.ua/laws/show/995_015

6. [Електронний ресурс]. - Режим доступу : https://zakon.rada.gov.ua/laws/show/995_043.

7. [Електронний ресурс]. - Режим доступу : https://zakon.rada.gov.ua/laws/show/994_029.

8. [Електронний ресурс]. - Режим доступу : https://www.1000dokumente.de/?c=dokument_de\&dokument=0014_ gru\&l=ru\&object=translation

9. [Електронний ресурс]. - Режим доступу : http://pravo.org.ua/img/books/files/1525439592pol_const_new_a5_ web.pdf

10. [Електронний ресурс]. - Режим доступу : https://legalns.com/\%D0\%BA\%D0\%BE\%D0\%BC\%D0\%BF\%D0\%B5 $\% \mathrm{D} 1 \% 82 \% \mathrm{D} 0 \% \mathrm{~B} 5 \% \mathrm{D} 0 \% \mathrm{BD} \% \mathrm{D} 1 \% 82 \% \mathrm{D} 0 \% \mathrm{BD} \% \mathrm{D} 1 \% 8 \mathrm{~B} \% \mathrm{D} 0 \% \mathrm{~B} 5$.

11. Рабінович П. М., Грищук О. В. Право людини на компенсацію моральної шкоди (загальнотеоретичні аспекти) : праці Львівської лабораторії прав людини і громадянина / П. М. Рабінович, О. В. Грищук. - Львів : Світ, 2006. - С. 12.

\section{References}

1. Onishchenko N. Svoboda gidnist' ta rivnist' lyudini kriz' evropejs'kij fokus / N. Onishchenko // Materiali mizhnarodnogo naukovo-praktichnogo seminaru, prisvyachenogo pam'yati L.Yuz'kova. - 2018. - S. 72-74.

2. Vdovichenko S. Pravo na lyuds'ku gidnist': ukraïns'ka teoriya i praktika u konteksti єvropejs'kogo dosvidu / S. Vdovichenko, V. Kampo // Visnik konstitucijnogo sudu Ukraïni . - 2012. - №4. - S. 56-68.

3. [Elektronnij resurs]. - Rezhim dostupu: http://www.irf.ua/knowledgebase/publications/npm_2013/6

4. Rozvadovs'kij V. Problemi pravovogo zahistu j ohoroni chesti ta gidnosti lyudini v Ukraïni/ V. Rozvadovs'kij // Materiali mizhnarodnogo naukovo-praktichnogo seminaru, prisvyachenogo pam'yati L.Yuz'kova. -2018. - S. 79-85.

5. [Elektronnij resurs]. - Rezhim dostupu: https://zakon.rada.gov.ua/laws/show/995_015.

6. [Elektronnij resurs]. - Rezhim dostupu: https://zakon.rada.gov.ua/laws/show/995_043.

7. [Elektronnij resurs]. - Rezhim dostupu: https://zakon.rada.gov.ua/laws/show/994_029.

8. [Elektronnij resurs]. - Rezhim dostupu: https://www.1000dokumente.de/?c=dokument_de\&dokument=0014_ gru\&l=ru\&object=translation.

9. [Elektronnij resurs]. - Rezhim dostupu: http://pravo.org.ua/img/books/files/1525439592pol_const_new_a5_web.pdf

10. [Elektronnij resurs]. - Rezhim dostupu: https://legalns.com/\%D0\%BA\%D0\%BE\%D0\%BC\%D0\%BF\% $\overline{0} \% \overline{\mathrm{D}} \% \overline{\mathrm{B}} \% \mathrm{~B} 5 \mathrm{DD}$ $1 \% 82 \% \mathrm{D} 0 \% \mathrm{~B} 5 \% \mathrm{D} 0 \% \mathrm{BD} \% \mathrm{D} 1 \% 82 \% \mathrm{D} 0 \% \mathrm{BD} \% \mathrm{D} 1 \% 8 \mathrm{~B} \% \mathrm{D} 0 \% \mathrm{~B} 5$.

11. Rabinovich P. M., Grishchuk O. V. Pravo lyudini na kompensaciyu moral'noï shkodi (zagal'noteorel'tichni aspekti) : praci L'vivs'koï laboratoriï prav lyudini i gromadyanina / P.M. Rabinovich,O. V. Grishchuk; APNU. NDI derzh. bud \'va ta misc. samovryaduvannya; Redkol. P. M. Rabinovich [ta in.]. - L'viv: SVIT, 2006. - S. 12. 
Марченко М. А. Нормативно-правове закріплення права на повагу до людської гідності в українській та свропейській правових системах (порівняльно-правовий аспект)

Дана стаття присвячена надзвичайно важливому питанню в правовій системі будь-якої країни, а саме - природному та невід'ємному праву людини на повагу до іiі гідності. У статті проведено аналіз досліджень провідних українських вчених, які вивчали проблематику нормативно-правового закріплення права на людську гідність. Особливий акцент зроблено на порівняльному аспекті нормативно-правового закріплення права особи на повагу до людської гідності в основоположних документах країн Європейського Союзу. Беручи до уваги зазначене, проаналізовано конституційні положення окремих країн-членів ЄС, які визнають право людини на повагу до їі гідності на рівні національних інтересів. Окрім цього, в контексті вітчизняної правової думки, нами було простежено перші згадки про необхідність конституційного закріплення вказаного права, з посиланням на європейський досвід у сфері захисту прав і свобод людини. Разом із аналізом конституційних положень щодо нормативних приписів про необхідність визнання права особи на повагу до ії гідності, акцентуємо увагу на нормах цивільного законодавства, які встановлюють юридичні підстави для захисту вказаного природного права. Щодо кримінально-правової відповідальності за порушення права особи на визнання ії гідності, то, сьогодні вона прямо не передбачена. Проте відповідальність за злочини, об'єктом яких виступає людська гідність, визначається відповідними статтями Кримінального кодексу України. На підставі аналізу норм вітчизняної правової системи з провідними нормативно-правовими актами країн Свропейського Союзу запропоновано шляхи вдосконалення стану захищеності права особи на повагу іiї гідності, як з теоретичної точки зору, так і на практиці.

Ключові слова: нормативно-правове закріплення, людина, права і свободи, право на гідність.

Marchenko M. A. Legal and regulatory consolidation of right to human dignity in Ukrainian and European legal frameworks (comparative and legal aspect)

This paper is dedicated to the high-priority problem of legal framework of any country, namely, to the natural and inherent right to human dignity. The paper analyses the leading Ukrainian scientists' studies of the issues of legal and regulatory consolidation of the right to human dignity. Thus, in different times, the said issue category was studied by: 1) N. Kuznetsova, 2) N. Onishchenko, 3) O. Petryshyn, 4) O. Skrypniuk, 5) S. Stetsenko, 6) S. Shevchuk, 7) Yu. Shemshuchenko, 8) O. Yushchyk. Particular emphasis was placed on the comparative aspect of legal and regulatory consolidation of human right to dignity in the underlying documents of the EU countries. Given the above, the paper investigates into constitutional provisions of separate EU member states, acknowledging the human right to dignity at the national interest level.

Besides, within the framework of the national legal thought, the author traced the first references to the necessity of constitutional consolidation of the specified right with reference to the European experience in the field of protection of human rights and liberties. Along with the analysis of constitutional provisions regarding regulatory prescriptions on the necessity to recognize the human right to dignity, the author points up civil law regulations establishing legal grounds for protection of the same natural right.

Social predicament of the investigated category of rights is out of question, however, unfortunately, criminal and legal accountability for infringement of the internationally recognized right to honor and dignity is not expressly regulated. In particular, accountability for the crimes against human dignity is provisioned in relevant clauses of the Criminal Code of Ukraine.

Thus, provisions of the third section of the Special Part of the Criminal Code of Ukraine called "Crimes Against Liberty, Honor and Dignity of a Person" establish criminal responsibility for illegal imprisonment or kidnapping (Cl. 146), taking hostages (Cl. 147), child substitution (Cl. 148), human trafficking or other illegal agreement regarding person (Cl. 149), child labor (Cl. 150), using minor children for begging $(\mathrm{Cl} .150-1)$ and illegal psychiatric detention $(\mathrm{Cl}$. 151).

Further, based on the results of analysis of international regulatory legal acts, fundamental laws of the EU member states, the Constitution of Ukraine and domestic statutory provisions, as well as law books and investigations of the leading scientists in the field of enforcement of human rights and liberties, there were suggested the ways to improve the state of protection of human right to dignity from a theoretical perspective, as well as in practice.

Key words: legal and regulatory consolidation, human, rights and liberties, right to dignity.

DOI: 10.33.66.3/2524-017X-2019-10-180-184 